\title{
Neuronal degeneration in autonomic nervous system of Dystonia musculorum mice
}

\author{
Kuang-Wen Tseng ${ }^{1 *}$, Mei-Lin Peng ${ }^{2}$, Yang-Cheng Wen ${ }^{1}$, Kang-Jen Liu ${ }^{1}$, Chung-Liang Chien ${ }^{3^{*}}$
}

\begin{abstract}
Background: Dystonia musculorum $(d t)$ is an autosomal recessive hereditary neuropathy with a characteristic uncoordinated movement and is caused by a defect in the bullous pemphigoid antigen 1 (BPAG1) gene. The neural isoform of BPAG1 is expressed in various neurons, including those in the central and peripheral nerve systems of mice. However, most previous studies on neuronal degeneration in BPAG1-deficient mice focused on peripheral sensory neurons and only limited investigation of the autonomic system has been conducted.

Methods: In this study, patterns of nerve innervation in cutaneous and iridial tissues were examined using general neuronal marker protein gene product 9.5 via immunohistochemistry. To perform quantitative analysis of the autonomic neuronal number, neurons within the lumbar sympathetic and parasympathetic ciliary ganglia were calculated. In addition, autonomic neurons were cultured from embryonic $d t / d t$ mutants to elucidate degenerative patterns in vitro. Distribution patterns of neuronal intermediate filaments in cultured autonomic neurons were thoroughly studied under immunocytochemistry and conventional electron microscopy.

Results: Our immunohistochemistry results indicate that peripheral sensory nerves and autonomic innervation of sweat glands and irises dominated degeneration in $d t / d t$ mice. Quantitative results confirmed that the number of neurons was significantly decreased in the lumbar sympathetic ganglia as well as in the parasympathetic ciliary ganglia of $d t / d t$ mice compared with those of wild-type mice. We also observed that the neuronal intermediate filaments were aggregated abnormally in cultured autonomic neurons from $d t / d t$ embryos.

Conclusions: These results suggest that a deficiency in the cytoskeletal linker BPAG1 is responsible for dominant sensory nerve degeneration and severe autonomic degeneration in $d t / d t$ mice. Additionally, abnormally aggregated neuronal intermediate filaments may participate in neuronal death of cultured autonomic neurons from $d t / d t$ mutants.
\end{abstract}

\section{Background}

Dystonia musculorum ( $d t$ ) is an autosomal recessive hereditary neuropathy in mice caused by the ablative bullous pemphigoid antigen 1 (BPAG1) gene [1]. The human homologue of the mouse sequence from the $d t$ locus is on chromosome 6p12 [2]. Heterozygous $d t$ mice appear normal phenotypically, but homozygous $d t$ mice develop dystonia. Young $d t / d t$ mutants are typically smaller than their normal littermates, and at approximately two weeks after birth, they exhibit abnormal

\footnotetext{
* Correspondence: kuangwen@mercury.csmu.edu.tw; chien@ntu.edu.tw ${ }^{1}$ School of Optometry, College of Medical Sciences and Technology, Chung Shan Medical University, Taichung, Taiwan

${ }^{3}$ Department of Anatomy and Cell Biology, College of Medicine, National Taiwan University, Taipei, Taiwan

Full list of author information is available at the end of the article
}

postures and progressive loss of movement coordination. Hyperflexion and pronation of foot paws are other symptoms $[3,4]$. Previous studies have demonstrated substantial degenerative alterations involving the peripheral and central sensory pathways, and spinal motor neurons are slightly affected [5]. This pathology appears primarily related to abnormal axonal accumulations of cytoskeleton in $d t / d t$ mice [5-8].

The cytoskeletal interacting protein, BPAG1, appears in several isoforms in different tissues [9]. The neural isoform of BPAG1 mRNA, BPAG1n, has been detected in a variety of neuronal systems during normal growth, such as in neurons within dorsal root ganglia, trigeminal ganglia, sympathetic ganglia, enteric nerve system, and spinal ventral horns [5]. BPAG1n is generally expressed in neurons in numerous regions in wild-type mice, but

\section{Biomed Central}


not all neurons deficient in BPAG1 cause serious degeneration in $d t / d t$ mice [5]. Most previous studies on neuronal degeneration in $d t / d t$ mice focused on the sensory nerve system $[3,5]$, whereas the autonomic nervous system was seldom addressed. In our previous study of spinal motor neurons in $d t / d t$ mice, no significant neuronal loss was observed in the spinal motor neurons [8]. However, the lifespan of these homozygous mutants is limited to three to four months. In human peripheral neuropathy, some evidences have indicated that sensory and autonomic neurons undergo degeneration together $[10,11]$. Autonomic neuronal degeneration and sensory deficiency are assumed to play key roles in the early mortality of $d t / d t$ mice.

Investigations have revealed that the cytoskeletal interacting protein, BPAG1n, interacts with microtubules, microfilaments and neuronal intermediate filaments (IFs) and plays an important role in maintaining cytoarchitectural integrity [9,12-14]. Pathological changes in $d t / d t$ axonal degeneration have been found together with aggregation of IFs [5,7]. Moreover, studies in transgenic mice and in transfected stable cell lines that overexpress neuronal IF have demonstrated abnormal IF accumulation in degenerating neurons $[15,16]$. These results may also be significant to neuronal diseases, in which IF protein aggregation plays an important role in neuronal degeneration. Abnormal IF protein aggregations in the cytoplasm are critical because the hyperphosphorylation of cytoplasmic IFs may trigger the neuronal death [17-19]. In clinical neuropathy, neurodegenerative disorders are morphologically represented by progressive neuronal degeneration and associated typical cytoskeletal change $[20,21]$. In addition, degenerative neurons with neuronal cytoplasmic inclusions have been observed in neuronal intermediate filament inclusions disease [22].

Neuroscience researchers are deeply concerned with elucidating the neuronal degeneration and apoptosis associated with human neurological diseases. Accordingly, the neurological mutant $d t / d t$ mouse can be adopted to examine the genetic and neurological basis of human diseases, such as peripheral nerve degeneration. The combination of impaired nociception and autonomic dysfunction, in which motor neurons were relatively or completely spared, is characteristic of autosomal recessive autonomic neuropathy [23]. An investigation of changes in peripheral innervation and neuronal number within the autonomic ganglia of $d t / d t$ may clarify the pathophysiology of mutation.

In this study, immunohistochemical analyses of cutaneous and iridial tissues, as well as autonomic neuronal counting within ganglia were performed on $d t / d t$ mice in vivo. Furthermore, to study patterns of neuronal IFs in autonomic neurons of $d t / d t$, sympathetic neurons were collected and assayed in vitro. Distribution patterns of neuronal IFs in cultured sympathetic ganglia neurons were studied thoroughly using immunocytochemistry and conventional electron microscopy.

\section{Materials and methods}

Mice

B6C3Fe-ala-Dst $t^{d t-J}$ mice, carrying a natural mutation in the BPAG1 gene, were utilized in this study. Experimental mice were collected from litters of heterozygous breeding pairs, provided by Jackson Laboratories (Bar Harbor, MA). Care and treatment of animals were in accordance with standard laboratory animal protocols approved by the Animal Care Committee (Chung Shan Medical University). A total of 26 adult mice (10 dt/dt and 16 wild-type) were selected by reverse transcriptasepolymerase chain reaction (RT-PCR) assays from litters of nine heterozygous breeding pairs for the following studies.

\section{RT-PCR assays}

Mice were sacrificed by cervical dislocation after anesthesia with choral hydrate $(400 \mathrm{mg} / \mathrm{kg}$ of body weight, intraperitoneally). Total RNA from the tissue samples was prepared using TRIzol reagent and converted to cDNA using a reverse primer and reverse transcriptase (Invitrogen Corp., Carlsbad, CA). To amplify the cDNA, this study used Taq DNA polymerase and PCR, consisting of 40 cycles at $94^{\circ} \mathrm{C}$ for $30 \mathrm{sec}, 65^{\circ} \mathrm{C}$ for $30 \mathrm{sec}$ and, $72^{\circ} \mathrm{C}$ for 1 minute. Specific PCR primer sequences were prepared as follows: BPAG1n primers (5'-GAC GAG AAG TCG GTG ATA ACC TAT G-3' and 3'-CTG TTT GAG TAG GAC GGG CTT-5', producing a 511-bp fragment). The primers of $\beta$-actin applied as the positive control, were 5'-AAC CAT GAG GGA AAT CGY GCA C-3' and 3'-AGT CAA GGG AAT CGG CAG AAT G-5' (producing a 219 bp fragment).

\section{Immunohistochemistry for nerve tissues in footpads}

The eight-week-old mice were anesthetized and perfused with $4 \%$ paraformaldehyde. Tissue samples were collected and then cut on a freezing microtome. Floating sections were transferred into phosphate-buffered saline (PBS) solution, incubated in 3.5\% hydrogen peroxide to eliminate endogenous peroxidase activity, and finally blocked using $5 \%$ normal goat serum and $0.5 \%$ Triton $\mathrm{X}-100$ in PBS. Sections were incubated with the primary antibody against neuronal marker proteins such as gene product 9.5 (PGP 9.5, 1: 500, Chemicon, Temecula, CA) at $4^{\circ} \mathrm{C}$ for $16-24$ hours. After rinsing in PBS, sections were incubated with biotinylated secondary antibody of the appropriate specie (Sigma-Aldrich, St. Louis, MO). The color reaction product was accomplished with a 
Vector $\mathrm{ABC}$ kit and with the 3, 3-diaminobenzadine (DAB) reaction (Vector Labs, Burlingame, CA).

\section{Immunohistochemistry of nerve fibers in iris}

To prevent the DAB color reaction from being covered up by pigment granules in the iris, the fluorescence immunohistochemistry was applied. Iridial wholemounts were labeled with pan neuronal marker using fluorescence-labeled secondary antibody. Irises were incubated for 24 hours in the pan neuronal marker primary antibody (PGP 9.5, Chemicon) at $4^{\circ} \mathrm{C}$. After washing, tissues were then reacted for 2 hours with FITC-conjugated goat anti-rabbit IgG (Sigma-Aldrich). Flat mounts were analyzed under a Zeiss Axiophot microscope (Carl Zeiss, Oberkochen, Germany).

\section{Quantifying neuronal number}

To perform quantitative analysis of the number of sympathetic neurons, lumbar ganglia were fully sectioned at a thickness of $8 \mu \mathrm{m}$. Every tenth section was subjected to examination to avoid double counting of cells, and a total of 15-20 sections were selected for each ganglion. Total number of neurons with both nucleus and nucleolus in the focal plane was counted. Statistical difference was determined by an analysis of Student's $t$-test.

In ciliary ganglia, a different approach was adopted given its small size. Serial sections $(8 \mu \mathrm{m})$ were stained with hematoxylin, and all neurons were counted throughout every section, covering the entire ciliary ganglia. Only cells with distinct nuclei were counted to avoid double counting of cells.

\section{Histograms of relative proportions of neuronal areas}

For histograms of relative proportions of neuronal areas, the method was modified from the study of dorsal root ganglia [24]. In sympathetic ganglia, the largest cross sections were chosen for cell counting to avoid double counting of cells. In ciliary ganglia, neurons were counted through sections $(8 \mu \mathrm{m})$ of whole ganglia. The area of neuron with distinct nucleoli was determined. The area of each neuron was determined using the image analysis software (Image-Pro Plus v. 4.5, Media Cybernetics, Silver Spring, MD). For construction of histogram, total counting number of neurons analyzed in each mouse was taken as $100 \%$. Neuronal size was sorted into groups at $50 \mu \mathrm{m}^{2}$ intervals and the percentage of neurons falling into these size ranges was calculated.

\section{Pupillary light reflex}

Pupillary responses were measured in unanesthetized age-matched eight-week-old wild-type and $d t / d t$ mice. Each animal was allowed to adapt to darkness for at least 30 minutes. Subsequently, mice were placed on a custom-built stereotactic apparatus, by which animal movement was restricted by a $28 \mathrm{~mm}$ diameter polyethylene tube. A beam of light was directed to the eye for evaluation of the pupillary light reflex. The pupillary diameter was measured and used to calculate pupil area.

\section{Cell culture for embryonic neurons from sympathetic ganglia in wild-type and $d t / d t$ mice}

To determine the effect of neuronal IF on developing sympathetic neurons, sympathetic ganglia were dissected and collected from mouse embryos at embryonic day 15.5. To determine the genotype each embryo from the heterozygous breeding, the spinal cord of each embryo was collected for RT-PCR analysis, as in our previous study [6]. Sympathetic ganglia collected from each embryo were treated with $0.25 \%$ trypsin without EDTA for 20 minutes at $37^{\circ} \mathrm{C}$. Cells from sympathetic ganglia were physically dissociated by pipetting, plated in culture dishes (Corning, New York, NY), and allowed to attach to coverslips plated with poly-D-lysine (SigmaAldrich). The culture medium was composed of Neurolbasal medium (Gibco, Grand Island, NY) supplemented with $20 \%$ fetal bovine serum, $2 \%$ glucose, $2.5 \mathrm{mM} \mathrm{L-glu-}$ tamine, 2\% B-27, and $100 \mathrm{ng} / \mathrm{mL}$ nerve growth factor ( $\mathrm{R}$ \& D Systems, Minneapolis, MN). Cultured sympathetic ganglia cells were collected at 5 days in vitro (DIV) for further analysis.

\section{Electron microscopy for cultured neurons}

Cultured cells were fixed with a fixative containing $4 \%$ paraformaldehyde and $1 \%$ glutaraldehyde in $0.1 \mathrm{M}$ cacodylate buffer ( $\mathrm{pH}$ 7.4). Following post-fixation in 1\% osmium tetroxide for 2 hours, tissues were dehydrated through a graded series of ethanol, and then embedded in Epon 812 resin. Ultrathin sections (70 nm-thick) were collected on copper grids, doubly stained with uranyl acetate and lead citrate, and observed under a Hitachi 7100 electron microscope (Hitachi, Tokyo, Japan).

\section{Immunocytochemistry for cultured neurons from sympathetic ganglia}

Embryonic neurons were cultured on poly-D-lysine coated glass coverslips in a cell culture dish. Cultured neurons were fixed in methanol for 30 minutes at $4^{\circ} \mathrm{C}$ and then permeabilized with $0.1 \%$ Triton X-100 in PBS for 5 minutes. After which, cells were incubated for 1 hour with primary antibodies against ubiquitin and medium-neurofilament (NF-M; Sigma-Aldrich), followed by washing three times in PBS. Samples were then incubated with secondary antibodies and Hoechst 33342 (SigmaAldrich) at $27^{\circ} \mathrm{C}$ for 1 hour. Hoechst 33342 was applied to stain nuclei. Subsequently, cultured neurons were mounted and examined under a Zeiss LSM 510 META confocal spectral microscope (Oberkochen, Germany). 


\section{Results}

Genetic characterization of $d t / d t$ mice

This study initially determined the expression patterns of BPAG1n mRNA from wild-type and $d t / d t$ mice by RT-PCR. The BPAG1n mRNA could be detected in the dorsal root, sympathetic, and ciliary ganglia of wild-type mice, but not in that of $d t / d t$ mice (Figure 1).

Sympathetic denervation in the sweat gland of $d t / d t$ mice To investigate sympathetic innervation, the skin of the footpad was immunoassayed using the antibody against PGP 9.5. In wild-type mice, various immunopositive nerves encircled the coiled tubules of sweat glands, forming an interlacing, dark, and continuous pattern (Figure $2 \mathrm{~A}$ and $2 \mathrm{~B}$ ). In $d t / d t$ mice, a few faintly stained immunopositive nerves were identified in the dermis of footpads (Figure 2C and 2D). In normal mice, numerous autonomic nerves encircled innervated sweat glands (Figure 2E and 2F). However, sweat glands were significantly denervated, with only weak and disorganized immunoreactivity around them (Figure 2G and $2 \mathrm{H}$ ). This observation, it may be implied that autonomic nerves innervated sweat glands were poor in $d t / d t$. Histopathological analysis revealed that sweat glands in $d t /$ $d t$ mutants were not significantly changed. The morphology of sweat glands in $d t / d t$ mutants does not differ in appearance compared with that in wild-type mice (Figure 2E and 2G).

Additionally, the morphology of lumbar sympathetic ganglia was investigated. Typical sympathetic neurons with visible nucleoli were observed in wild-type mice (Figure Figures. 2I and 2J). The neuronal number was significantly reduced upon observation under quantitative analysis (Table 1 and Figure $2 \mathrm{~K}$ ), and more glial cells could be easily identified in the ganglia of $d t / d t$ mice (Figure 2L).

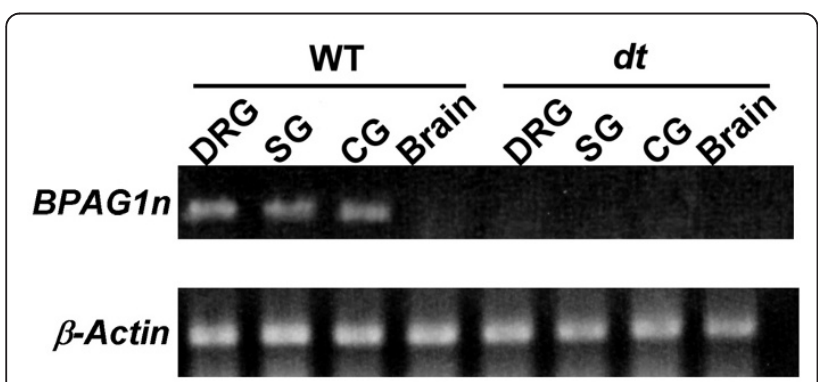

Figure 1 RT-PCR analysis of BPAG $1 n$ and $\beta$-actin mRNAs from wild-type and $\boldsymbol{d} \boldsymbol{t} / \boldsymbol{d} \boldsymbol{t}$ mice. BPAG1n mRNA could be detected in dorsal root ganglia, sympathetic ganglia, and ciliary ganglia of wildtype mice, but not in $d t / d t$ mice. $\beta$-Actin primers were used as positive controls.
Density of parasympathetic nerve significantly decrease in the iris of $d t / d t$ mice

In irises, the wider diameter of pupil size was noticeable in $d t / d t$ mice (Figure $3 \mathrm{~A}$ and $3 \mathrm{~B}$ ). Dual autonomic innervation occurred in both sphincter and dilator muscles of the iris. In the wholemount iris of $d t / d t$ mice, immunopositive fibers showed a marked decrease in density throughout the sphincter and dilator area compared with the intact control iris from wild-type mice (Figure 3A and 3B).

Parasympathetic ciliary ganglion and short ciliary nerve running along the outer surface of the optic nerve could be identified in wild-type mice (Figure 3C). In contrast, the smaller ciliary ganglion and ciliary nerve bundle could be found in $d t / d t$ mice (Figure $3 \mathrm{D}$ ). To illustrate the relationship between the denervation and parasympathetic neuropathy of $d t / d t$ mice, neurons in ciliary ganglia were examined as well. We found that the neuronal number was reduced in ciliary ganglia of $d t / d t$ mice (Table 1, Figure $3 \mathrm{E}$ and $3 \mathrm{~F}$ ). These observations suggest that the parasympathetic innervation of irises is poorer in $d t / d t$ mice compared with those in wild-type mice. To investigate the functional defect of autonomic denervation in irises of $d t / d t$ mice, the lightinduced pupillary reflex was examined. From the pupillary reflex function test, the pupillary diameter size was notably wider and the iris constriction was weaker in terms of the response to light in $d t / d t$ mice compared with that in wild-type mice (Figure $3 \mathrm{G}$ and $3 \mathrm{H}$ ).

\section{Decrease in neuron size in sympathetic ganglia and ciliary ganglia of $d t / d t$ mice}

To examine the difference in neuronal size of autonomic ganglia between $d t / d t$ and wild-type mice, we quantified the cross-sectional areas of neurons in sympathetic ganglia and in ciliary ganglia of $d t / d t$ and wildtype mice. Histograms of relative proportions documented a large peak between 401 and $450 \mu \mathrm{m}^{2}$ in wild-type mice, whereas between 301 and $350{\mu \mathrm{m}^{2}}^{2}$ in $d t / d t$ mice (Figure 4A and 4a1-a4). The greatest proportion of neuron area in ciliary ganglia ranged between 351 and 400 $\mu \mathrm{m}^{2}$ in wild-type mice, whereas the greatest proportion ranged between 301 and $350 \mu^{2}$ in $d t / d t$ mice (Figure $4 \mathrm{~B}$ and $4 \mathrm{~b} 1-\mathrm{b} 4)$. Besides neuronal loss of both sympathetic and ciliary ganglia, our data also revealed a decrease in neuron size in sympathetic and ciliary ganglia of $d t / d t$ mice.

Neuronal IF aggregates and apoptosis-like death of cultured sympathetic neurons from $d t / d t$ embryos In cultured sympathetic neurons from $d t / d t$ embryos at $5 \mathrm{DIV}$, massive accumulation of neuronal IFs could be observed in cell processes (Figure 5A and 5B). The density of IFs was very high and the pattern of IFs was 


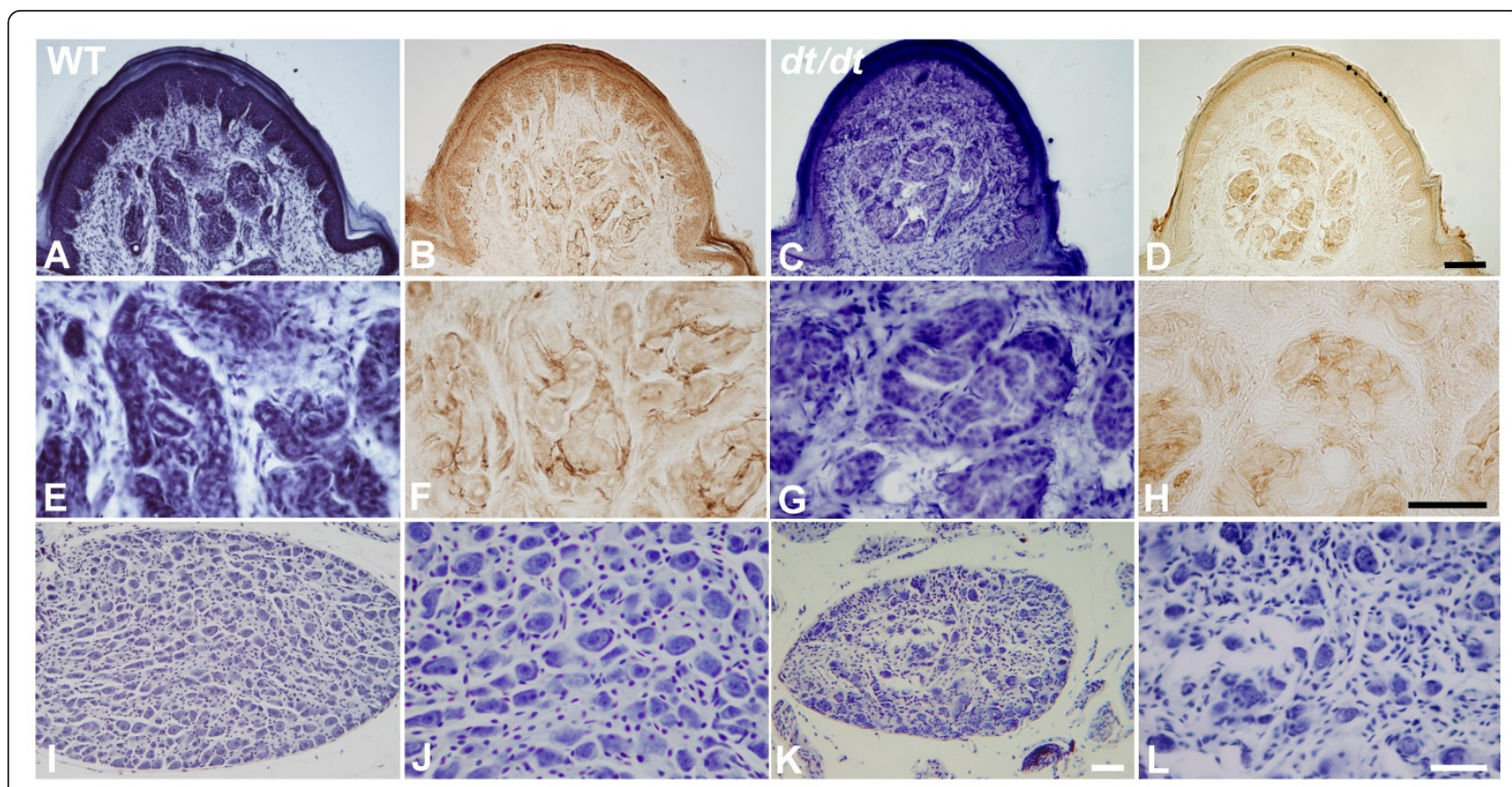

Figure 2 Localization of sympathetic nerves around sweat glands and neurons in sympathetic ganglion of wild-type and $d t / d t$ mice. Serial sections of footpads were stained with hematoxylin or antibody against PGP 9.5 in wild-type (A, B, E and F) and dt/dt mice (C, D, G and H). In normal mice skin, numerous PGP 9.5-immunoreactive autonomic fibers were visible in dermis (A and B). Conversely, only some nerve fibers were identifiable in $d t / d t$ mice (C and D). High-power photomicrographs revealed that autonomic nerves innervated sweat gland and displayed dense and strong PGP 9.5 immunoreactivity in normal skin ( $E$ and F), whereas only fragmented autonomic nerves could be observed in $d t / d t$ mice ( $\mathrm{G}$ and $\mathrm{H}$ ). From the observation of lumbar sympathetic ganglia, many neurons could be recognizable in the section of ganglia of wildtype mice ( $($ and J). However, only fewer neurons could be found in $d t / d t$ mice compared with wild-type mice $(\mathrm{K}$ and $\mathrm{L})$. Scale bars $=40 \mu \mathrm{m}$ in A-H; $50 \mu \mathrm{m}$ in I-L.

randomly oriented. Some entrapped organelles together with IF aggregates were found in the cellular process of cultured sympathetic neurons from $d t / d t$ mutants (Figure 5A).

Morphological patterns of cultured sympathetic neurons from wild-type mice were normal (Figure 6A). However, prominent vacuolization, typical autophagosomal structures and condensed chromatin could be found in cultured neurons of $d t / d t$ mice under light and electron microscopy (Figure 6B-E). Multi-membraned structures, including late lysosomes and

Table 1 Number of neurons in young adult $d t / d t$ mice compared with those in age-matched wild-type mice

\begin{tabular}{llcc}
\hline & Region & \multicolumn{2}{c}{ Neuronal number } \\
& & wild-type & $\boldsymbol{d t} / \boldsymbol{d t}$ \\
\hline Types of & Lumbar sympathetic & $2147 \pm$ & $736 \pm 362^{*}$ \\
neuron & ganglia & 131 & \\
& Ciliary ganglia & $187 \pm 9$ & $80 \pm 29^{*}$ \\
\hline
\end{tabular}

The neuronal numbers of ganglia were calculated from wild-type $(n=5)$ and $d t / d t(n=4)$ mice. Neurons with both the nucleus and nucleolus in the focal plane were counted. Results are expressed as mean $\pm S D$ and *indicates a value statistically different $(t$-test, $P<0.01)$ from the wild-type control. The neuronal number in sympathetic ganglia and parasympathetic ciliary ganglia of $d t / d t$ is significantly reduced compared with those of wild-type mice. autophagosomes, could be found in the cultured neurons, suggesting that cells are attempting to clean up the damaged organelles (Figure 6E). Some cultured neurons with numerous vacuolizations in cytoplasma of $d t / d t$ exhibited apoptosis-like death (Figure 6D). The chromatin condensation with intact cell membrane could be observed in degenerative neurons from $d t / d t$ (Figure 6C and 6D).

\section{Patterns of ubiquitin in degenerating neuron with IFs accumulation}

To determine the relationship between IFs and degrading proteins, NF-M and ubiquitin were examined by immunocytochemistry. At 5 DIV, cultured sympathetic neurons from wild-type mice highly expressed NF-M, but not ubiquitin (Figure 7A-D). Neuronal intermediate filament protein NF-M was normally distributed in axonal processes. However, the two proteins of ubiquitin and NF-M could be colocalized in the perikaryon of cultured sympathetic neurons from $d t / d t$ mice (Figure 7E$\mathrm{H})$. Based on confocal microscopy, the distribution of ubiquitin protein was associated with the abnormal accumulation of neuronal IFs aggregates in degenerative sympathetic neurons from $d t / d t$ mutants. 


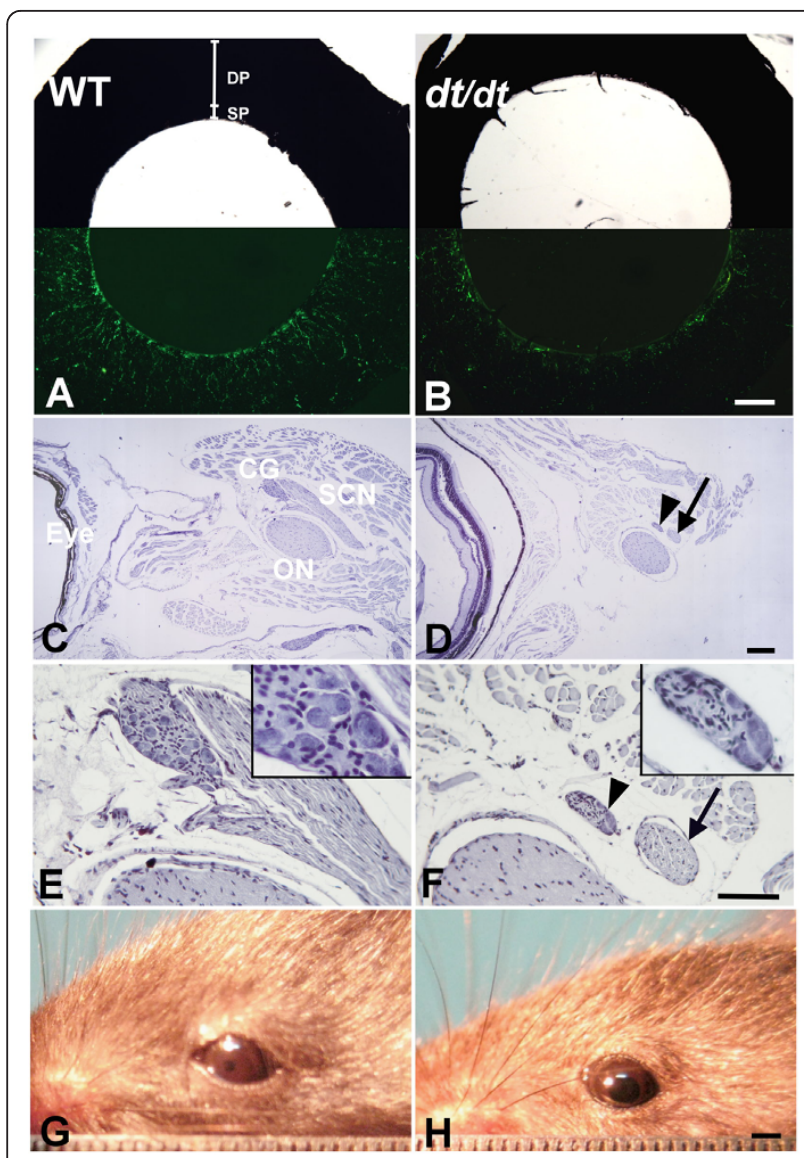

Figure 3 Nerve degeneration in irises and notably wider pupils in response to light of $d t / d t$ mice. Wholemount preparations of irises were stained by immunofluorescence for pan neuronal marker PGP 9.5 (A and B). In wild-type mice, PGP 9.5-positive fibers were circumferentially distributed along the pupillary ruff in the sphincter pupillae (SP) area and were radially oriented toward the pupil in the dilator pupillae (DP) area (A). Compared with intact wild-type mice, a few remaining immunopositive fibers exhibited marked decrease in density throughout the sphincter and dilator area in $d t / d t$ mice (B). Ciliary ganglion (CG) and short ciliary nerve (SCN) could be found along the outer surface of the optic nerve $(\mathrm{ON})$ in wild-type mice (C). However, the smaller nerve bundle (arrow) and ganglion (arrowhead) could be observed in $d t / d t$ mice (D). High-power photomicrographs revealed that the ganglion with typical neuronal morphology was observed in wild-type mice (E), whereas the ganglion with fewer number and smaller size of neurons could be found in $d t / d t$ mice (F). To investigate the denervation effect in the iris of $d t / d t$ mice, the light-induced pupillary reflex was tested. The pupillary diameter was narrower in wild-type mice during the pupillary reflex test $(G)$, whereas the pupil was notably wider and iris constriction was weaker in response to light in $d t / d t$ mice $(H)$. Scale bars $=200 \mu \mathrm{m}$ in A-F; $2 \mathrm{~mm}$ in $\mathrm{G}$ and $\mathrm{H}$.

\section{Discussion}

\section{Autonomic denervation in sweat glands and irises of $d t /$} dt mice

Previous studies revealed the expression of BPAG1n in a variety of sensory and motor neurons from the embryonic to the postnatal stage in normal development. However, morphometric study has shown sensory innervations is significantly reduced in $d t / d t$ mutants $[3,5,7,8]$. This study indicates that the sensory nerve is not only markedly denervated in the cutaneous part of footpads, but that sympathetic innervation is also severely impaired in sweat glands of young adult $d t / d t$ mice. The sympathetically innervated sweat glands substantially degenerated in footpads of $d t / d t$ mice. This degeneration pattern was demonstrated with immunohistochemistry using general neuronal marker PGP 9.5. Our new finding of the sympathetic denervation adds another criterion for phenotyping $d t / d t$ mice.

Ciliary ganglion, like sympathetic ganglion, is a neural crest-derived parasympathetic ganglion [25,26]. From our observation, the neuronal number of ciliary ganglion was significantly decreased in $d t / d t$ mice. Moreover, the functional assay provides compelling evidence regarding denervation of irises and the wider iridial diameter of pupillary response to light in $d t / d t$ mice. Based on these findings, we hypothesize that BPAG1 gene has an important role in the normal development of the ciliary ganglion. The loss of BPAG1n, a cytoskeleton linker protein, in neurons of sympathetic and parasympathetic ganglia suggests that the cytoskeletal dysfunction may trigger the neuronal death during cell migration. This phenomenon may account for the expression of $B P A G 1 n$ in numerous neurons during normal development, but neuronal degeneration is limited to peripheral neurons derived from neural crest cells in BPAG1-deficient mice.

The autonomic system is considered unaffected by neurodegenerative disorders such as X-linked recessive spinobulbar muscular atrophy and Guillain-Barre syndrome, but observations have revealed autonomic skin denervation $[27,28]$. This investigation also demonstrated the sympathetic denervation of sweat glands in footpads and parasympathetic denervation of irises in eyes of $d t / d t$ mutants. The terminal endings of the sympathetic nerve commonly degenerate more quickly than the proximal portions of the degenerating sympathetic ganglia neurons [29]. Skin denervation studies have established an early sign of neuropathy before ganglionopathy is detected [30]. From our studies, cutaneous tissues and iridial wholemounts with immunohistochemical analysis constitute a reliable approach for distinguishing between neuropathy and neuronopathy. Our data provides an evidence of epidermal and iridial denervation in footpads and eyes with autonomic neuropathy in neuronal cytoskeletal dysfunction.

\section{Roles of neuronal cytoskeletons in cultured sympathetic neurons from $d t / d t$ embryos}

Clinical and basic neuropathy has indicated that neurodegenerative disorders are morphologically represented 


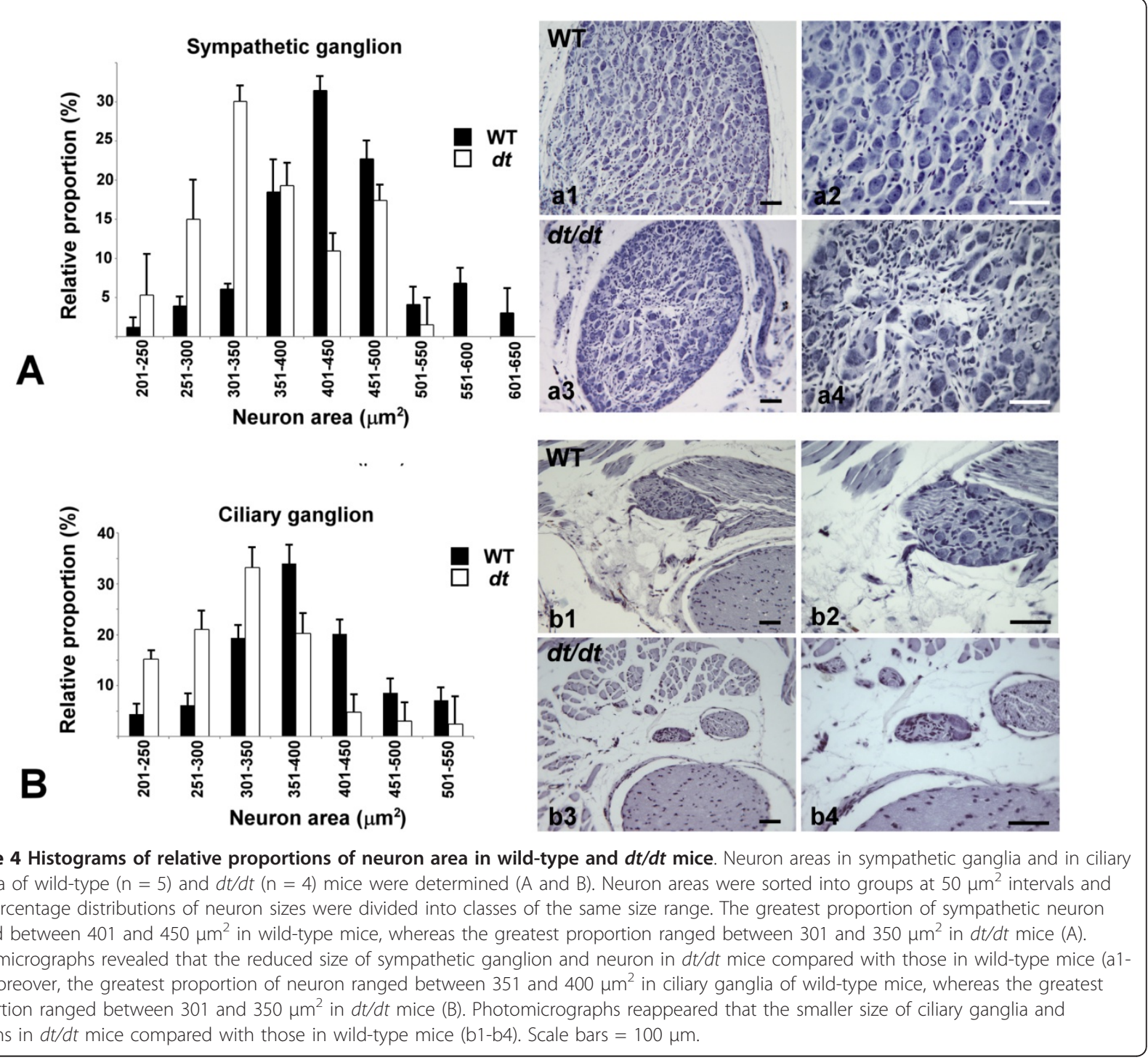

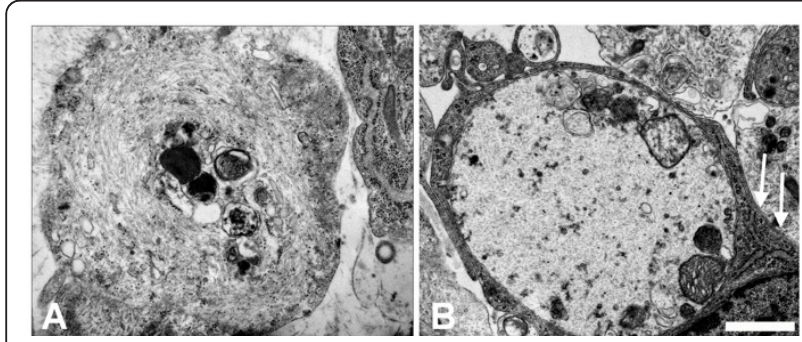

Figure 5 Ultrastructural patterns of neuronal IFs aggregates in degenerating cultured sympathetic neurons from $d t / d t$ embryos. At the ultrastructural level, IF aggregates and randomly oriented IFs were observed in cultured sympathetic neurons from embryonic $d t / d t$ mice (A). Neuronal IFs formed aggregates in soma, suggesting its involvement in the degeneration of neurons from $d t$ / $d t$ mice. Random orientation of IFs and axonal organelles was observed in the swelling processes of sympathetic neurons from $d t /$ $d t$ embryos (B). The swelling process was surrounded by a Schwann cell (arrows, B). Scale bars $=1 \mu \mathrm{m}$. by progressive neuronal damage and are associated with the typical cytoskeleton dysfunction $[15,16,20,21]$. Other results have also indicated that abnormal aggregations of IF proteins are significantly involved in the mechanism of neuronal death $[22,31,32]$. In the previous study of $d t / d t$ mice, the abnormal accumulation of IFs in degenerating primary sensory neurons was observed in vivo and in vitro [7]. The abnormal accumulation of neuronal IF proteins may impair axonal transport and later trigger neuronal apoptosis cascade of neurons in dorsal root ganglia of $d t / d t$ [7]. In our current study, abnormal translocation of neuronal IFs was also found in the nerve process and soma of cultured sympathetic neurons from $d t / d t$ embryos. It suggests that the deficiency in BPAG1, the cytoskeletal linker protein, may induce neuronal death in the sympathetic nervous system of $d t / d t$ mice during development. 


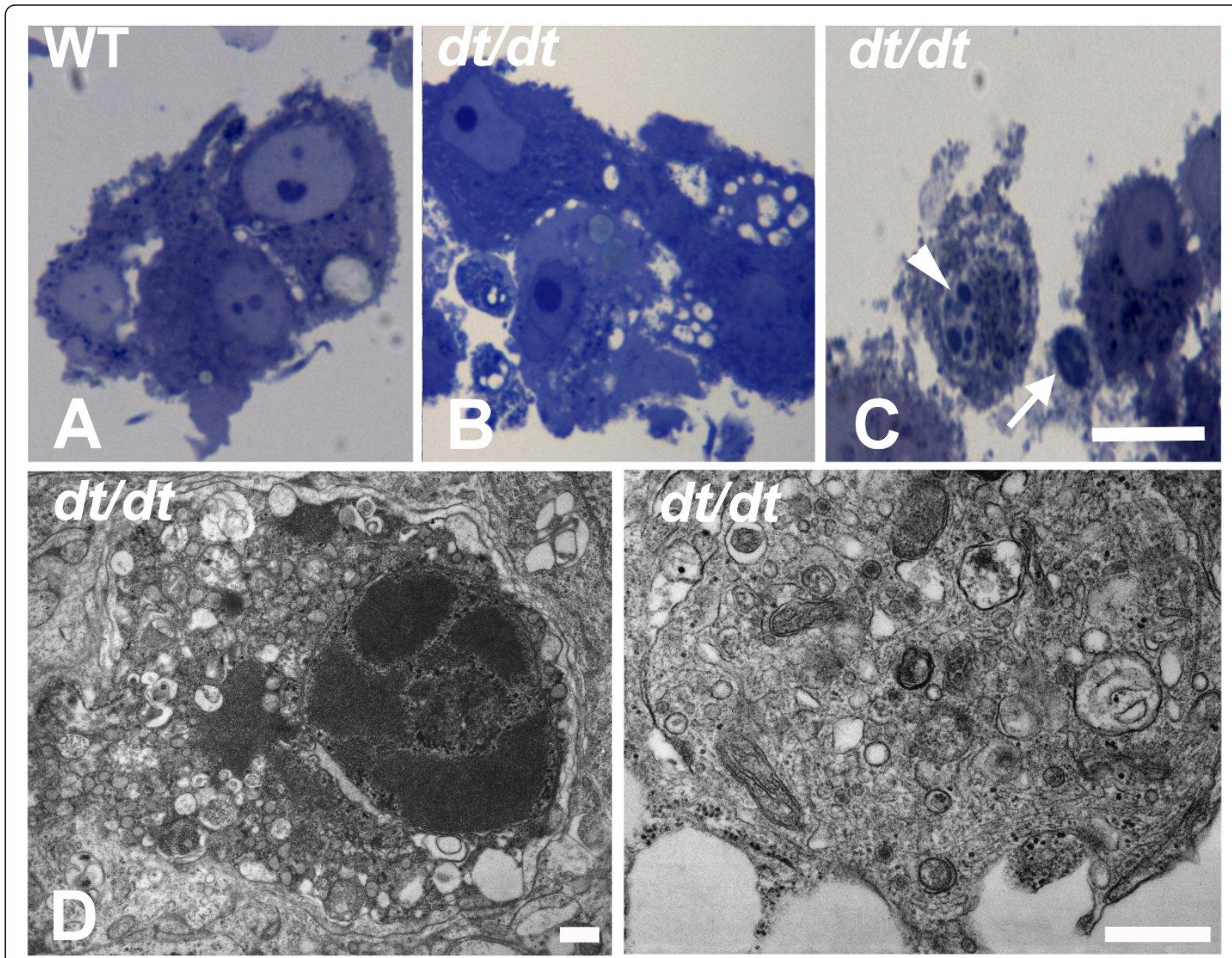

Figure 6 Vacuolization and chromatin condensation of cultured sympathetic neurons from $\boldsymbol{d t} / \boldsymbol{d t}$ mice. In semithin sections, the morphological patterns of cultured neurons were normal from wild-type mice (A). However, certain membrane-bounded vesicles in the perikaryon (B) and chromatin condensation (arrowhead, C) could be found in cultured neurons of $d t / d t$ mutants. Aside from sympathetic neurons, a Schwann cell could be also found in this primary culture (arrow, C). At the ultrastructural level, images of cultured neurons reveal autophagic structures and prominent vacuolization from $d t / d t$ mice ( $D$ and $E$ ). Furthermore, the apoptosis-like characteristic of chromatin condensation with intact nuclear envelope and cell membrane could be observed from $d t / d t$ embryos (D). Multi-membraned autophagosomes could be found in the cytoplasm of $d t / d t$ mutants (E). Scale bars $=20 \mu \mathrm{m}$ in A-C; $1 \mu \mathrm{m}$ in D and $\mathrm{E}$.

\section{Protein degradation in degenerating neurons from $d t / d t$ mutants}

Intracellular protein degradation is mainly mediated by the ubiquitin-proteasome and autophagy-lysosome systems in eukaryotic cells $[33,34]$. Ubiquitin-proteasome system is chiefly responsible for degrading short-lived proteins and a selective form of catabolism [33]. Repetition of the cycle generates polyubiquitin chains on target proteins, which are then degraded into smaller peptides. In contrast, autophagy is a broad term for the degradation of long-lived proteins and a nonselective form of catabolism [34]. Some studies have revealed that abnormal protein aggregations, which are potential toxins, could be quickly degraded by the ubiquitin- proteasome and autophagy-lysosome systems [35,36]. Our immunomicroscopy images show the involvement of ubiquitin in degenerating neurons from $d t / d t$. In addition, preliminary transmission electron micrographs reveal lysosomal or autophagosomal structures and pronounced vacuolization in the cultured sympathetic neurons. Based on our observation, both ubiquitinproteasome and autophagy-lysosome systemsmayhave essential roles in degrading neuronal IFs aggregations in sympathetic neurons of $d t / d t$ mutants.

\section{Conclusion}

We have demonstrated the epidermal and iridial denervation associated with autonomic neuropathy of $d t / d t$ 


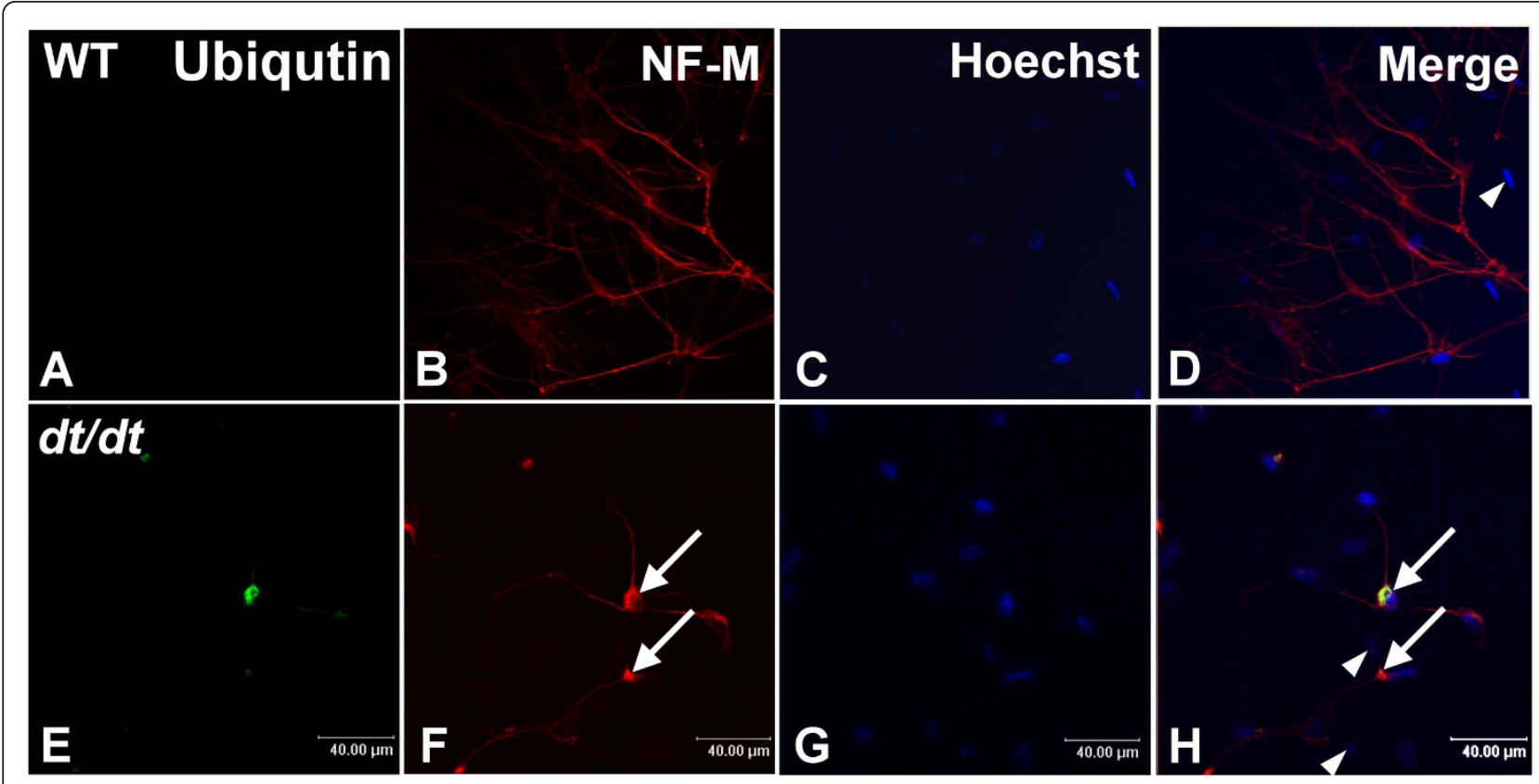

Figure 7 Immunoreactivity of ubiquitin and NF-M in cultured neurons from wild-type and $d t / d t$ mice. Cultured neurons were doublelabeled with antibodies against ubiquitin (green) and neuronal intermediate filament protein NF-M (red), and their nuclei were stained with Hoechst 33342 (blue). The ubiquitin-positive reaction was hardly noticeable in neurons of wild-type mice (A-D). Cultured neurons with abnormal accumulations of NF-M were mostly observed in the proximal region of axons and within cell bodies of cultured sympathetic neurons from $d t / d t$ mutants (F, arrows). Some neurons with NF-M accumulations could also be labeled with the antibody against the ubiquitin (E-H). Some smaller nuclei of non-neuronal cells were also observed in the primary culture (arrowheads, D and H). Scale bars $=40 \mu \mathrm{m}$.

mutants. Additionally, abnormally aggregated neuronal IFs may participate in neuronal death of cultured autonomic neurons from $d t / d t$ mutants. Our results suggest that a deficiency in the cytoskeletal linker BPAG1 is responsible for dominant sensory nerve degeneration and severe autonomic degeneration in $d t / d t$ mice.

\footnotetext{
Abbreviations

dt: dystonia musculorum; BPAG1: bullous pemphigoid antigen 1; BPAG1n: neural isoform of BPAG1; PGP 9.5: protein gene product 9.5; IFs: intermediate filaments; RT-PCR: reverse transcriptase-polymerase chain reaction; PBS: phosphate-buffered saline; DAB: 3, 3-diaminobenzadine; NF-M: mediumneurofilament;
}

\section{Acknowledgements}

The authors would like to thank the National Science Council of the Republic of China, Taiwan, for financially supporting this research under Grant no. NSC 97-2320-B-040-009-MY2 to K.W. Tseng and NSC 97-2628-B002-043-MY3 to C.L. Chien. Facilities provided by grants from the Ministry of Education, Taiwan to the NTU Center of Genomic Medicine are also acknowledged.

\section{Author details}

${ }^{1}$ School of Optometry, College of Medical Sciences and Technology, Chung Shan Medical University, Taichung, Taiwan. ${ }^{2}$ Department of Ophthalmology, Chung Shan Medical University Hospital, Taichung, Taiwan. ${ }^{3}$ Department of Anatomy and Cell Biology, College of Medicine, National Taiwan University, Taipei, Taiwan.

\section{Authors' contributions}

KWT and CLC designed, carried out the main experiment and drafted the manuscript. MLP helped design the experiment and improve the manuscript. YJW and KJL participated in immunohistochemistry assay and statistical analysis. All authors read and approved the final manuscript.

\section{Competing interests}

The authors declare that they have no competing interests.

Received: 20 October 2010 Accepted: 28 January 2011

Published: 28 January 2011

\section{References}

1. Brown A, Bernier G, Mathieu M, Rossant J, Kothary R: The mouse dystonia musculorum gene is a neural isoform of bullous pemphigoid antigen 1 . Nat Genet 1995, 10:301-306.

2. Brown A, Lemieux N, Rossant J, Kothary R: Human homolog of a mouse sequence from the dystonia musculorum locus is on chromosome $6 \mathrm{p} 12$. Mamm Genome 1994, 5:434-437.

3. Duchen LW, Strich SJ, Falconer DS: Clinical and pathological studies of an hereditary neuropathy in mice (Dystonia Musculorum). Brain 1964, 87:367-378.

4. Bernier G, De Repentigny Y, Mathieu M, David S, Kothary R: Dystonin is an essential component of the Schwann cell cytoskeleton at the time of myelination. Development 1998, 125:2135-2148.

5. Dowling J, Yang Y, Wollmann R, Reichardt LF, Fuchs E: Developmental expression of BPAG1-n: insights into the spastic ataxia and gross neurologic degeneration in dystonia musculorum mice. Dev Biol 1997, 187:131-142

6. Sotelo C, Guenet JL: Pathologic changes in the CNS of dystonia musculorum mutant mouse: an animal model for human spinocerebellar ataxia. Neuroscience 1988, 27:403-424.

7. Tseng KW, Lu KS, Chien CL: A possible cellular mechanism of neuronal loss in the dorsal root ganglia of Dystonia musculorum (dt) mice. $J$ Neuropathol Exp Neurol 2006, 65:336-347

8. Tseng KW, Chau YP, Yang MF, Lu KS, Chien CL: Abnormal cellular translocation of alpha-internexin in spinal motor neurons of Dystonia musculorum mice. J Comp Neurol 2008, 507:1053-1064. 
9. Leung $\mathrm{CL}$, Green KJ, Liem RK: Plakins: a family of versatile cytolinker proteins. Trends Cell Biol 2002, 12:37-45.

10. Dyck PJ, Dyck PJ, Schaid DJ: Genetic heterogeneity in hereditary sensory and autonomic neuropathies: the need for improved ascertainment. Muscle Nerve 2000, 23:1453-1455.

11. Verze L, Viglietti-Panzica C, Plumari L, Calcagni M, Stella M, Schrama LH, Panzica GC: Cutaneous innervation in hereditary sensory and autonomic neuropathy type IV. Neurology 2000, 55:126-128.

12. Yang Y, Dowling J, Yu QC, Kouklis P, Cleveland DW, Fuchs E: An essential cytoskeletal linker protein connecting actin microfilaments to intermediate filaments. Cell 1996, 86:655-665.

13. Leung $C L$, Sun D, Zheng M, Knowles DR, Liem RK: Microtubule actin crosslinking factor (MACF): a hybrid of dystonin and dystrophin that can interact with the actin and microtubule cytoskeletons. J Cell Biol 1999, 147:1275-1286.

14. Sun D, Leung CL, Liem RK: Characterization of the microtubule binding domain of microtubule actin crosslinking factor (MACF): identification of a novel group of microtubule associated proteins. J Cell Sci 2001, 114:161-172.

15. Ching GY, Chien CL, Flores R, Liem RK: Overexpression of alpha-internexin causes abnormal neurofilamentous accumulations and motor coordination deficits in transgenic mice. J Neurosci 1999, 19:2974-2986.

16. Chien $\mathrm{CL}$, Liu TC, Ho CL, Lu KS: Overexpression of neuronal intermediate filament protein alpha-internexin in PC12 cells. J Neurosci Res 2005, 80:693-706.

17. Nixon RA: The regulation of neurofilament protein dynamics by phosphorylation: clues to neurofibrillary pathobiology. Brain Pathol 1993, 3:29-38.

18. Lariviere RC, Julien JP: Functions of intermediate filaments in neuronal development and disease. J Neurobiol 2004, 58:131-148.

19. Pierozan P, Zamoner A, Soska AK, Silvestrin RB, Loureiro SO, Heimfarth L, Mello e Souza T, Wajner M, Pessoa-Pureur R: Acute intrastriatal administration of quinolinic acid provokes hyperphosphorylation of cytoskeletal intermediate filament proteins in astrocytes and neurons of rats. Exp Neurol 2010, 224:188-196.

20. Jellinger KA, Bancher C: Neuropathology of Alzheimer's disease: a critical update. J Neural Transm Suppl 1998, 54:77-95.

21. Dickson TC, King CE, McCormack GH, Vickers JC: Neurochemical diversity of dystrophic neurites in the early and late stages of Alzheimer's disease. Exp Neurol 1999, 156:100-110

22. Cairns NJ, Grossman M, Arnold SE, Burn DJ, Jaros E, Perry RH, Duyckaerts C, Stankoff B, Pillon B, Skullerud K, Cruz-Sanchez FF, Bigio EH, Mackenzie IR, Gearing M, Juncos JL, Glass JD, Yokoo H, Nakazato Y, Mosaheb S, Thorpe JR, Uryu K, Lee VM, Trojanowski JQ: Clinical and neuropathologic variation in neuronal intermediate filament inclusion disease. Neurology 2004, 63:1376-1384

23. Rotthier A, Baets J, De Vriendt E, Jacobs A, Auer-Grumbach M, Levy N, BonelloPalot N, Kilic SS, Weis J, Nascimento A, Swinkwls M, Kruyt MC, Jordanova A, De Jonghe P, Timmerman V: Genes for hereditary sensory and autonomic neuropathies: a genotype-phenotype correlation. Brain 2009, 132:2699-2711.

24. Schlegel N, Asan E, Hofmann GO, Lang EM: Reactive changes in dorsal roots and dorsal root ganglia after C7 dorsal rhizotomy and ventral root avulsion/replantation in rabbits. J Anat 2007, 210:336-351.

25. Weston JA: A radioautographic analysis of the migration and localization of trunk neural crest cells in the chick. Dev Biol 1963, 6:279-310.

26. Lee VM, Sechrist JW, Luetolf S, Bronner-Fraser M: Both neural crest and placode contribute to the ciliary ganglion and oculomotor nerve. Dev Biol 2003, 263:176-190.

27. Pan CL, Tseng TJ, Lin YH, Chiang MC, Lin WM, Hsieh ST: Cutaneous innervation in Guillain-Barré syndrome: pathology and clinical correlations. Brain 2003, 126:386-397.

28. Manganelli F, lodice V, Provitera V, Pisciotta C, Nolano M, Perretti A, Santoro L: Small-fiber involvement in spinobulbar muscular atrophy (Kennedy's disease). Muscle Nerve 2007, 36:816-820.

29. Mundinger TO, Mei Q, Taborsky GJ Jr: Impaired activation of celiac ganglion neurons in vivo after damage to their sympathetic nerve terminals. J Neurosci Res 2008, 86:1981-1993.

30. Lauria G, Sghirlanzoni A, Lombardi R, Pareyson D: Epidermal nerve fiber density in sensory ganglionopathies: clinical and neurophysiologic correlations. Muscle Nerve 2001, 24:1034-1039.
31. Bigio EH, Lipton AM, White CL III, Dickson DW, Hirano A: Frontotemporal and motor neurone degeneration with neurofilament inclusion bodies: additional evidence for overlap between FTD and ALS. Neuropathol Appl Neurobiol 2003, 29:239-253.

32. Josephs KA, Holton JL, Rossor MN, Braendgaard H, Ozawa T, Fox NC, Petersen RC, Pearl GS, Ganguly M, Rosa P, Laursen H, Parisi JE, Waldemar G, Quinn NP, Dickson DW, Revesz T: Neurofilament inclusion body disease: a new proteinopathy? Brain 2003, 126:2291-2303.

33. Ciechanover A, Orian A, Schwartz AL: Ubiquitin-mediated proteolysis: biological regulation via destruction. Bioessays 2000, 22:442-451.

34. Ahlberg J, Marzella L, Glaumann H: Uptake and degradation of proteins by isolated rat liver lysosomes. Suggestion of a microautophagic pathway of proteolysis. Lab Invest 1982, 47:523-532.

35. Hershko A, Ciechanover A: The ubiquitin system. Annu Rev Biochem 1998 67:425-479.

36. Yamamoto A, Cremona ML, Rothman JE: Autophagy-mediated clearance of huntingtin aggregates triggered by the insulin-signaling pathway. J Cell Biol 2006, 172:719-731.

doi:10.1186/1423-0127-18-9

Cite this article as: Tseng et al:: Neuronal degeneration in autonomic nervous system of Dystonia musculorum mice. Journal of Biomedical Science 2011 18:9.

\section{Submit your next manuscript to BioMed Central and take full advantage of:}

- Convenient online submission

- Thorough peer review

- No space constraints or color figure charges

- Immediate publication on acceptance

- Inclusion in PubMed, CAS, Scopus and Google Scholar

- Research which is freely available for redistribution

Submit your manuscript at www.biomedcentral.com/submit
Biomed Central 